\title{
FUNGUS-ASSISTED REINTRODUCTION AND LONG-TERM SURVIVAL OF TWO MEXICAN TERRESTRIAL ORCHIDS IN THE NATURAL HABITAT
}

\author{
M. Pilar Ortega-Larrocea ${ }^{1,2} \&$ Monica Rangel-Villafranco ${ }^{1}$ \\ 'Departamento de Edafología, Instituto de Geología, Universidad Nacional Autónoma de México. Circuito \\ Exterior de Ciudad Universitaria, México Distrito Federal, 04510. México. \\ ${ }^{2}$ Author for correspondence: mpol@geologia.unam.mx
}

KEY WoRDS: reintroduction, symbiotic propagation, terrestrial orchids, Mexican orchids

\begin{abstract}
Preservation of genetic diversity of orchids for conservation and restoration purposes is now a feasible practice after the ecological studies of seed bank dynamics made by several investigators (Batty et al. 2001, Whigham et al. 2006). However, few studies have demonstrated the reliability of reintroduction of several species into their natural habitat and less, managing symbiotic fungus (Ramsay and Dixon
\end{abstract} 2003, Zettler et al. 2003). The main problem is the survival monitoring of reintroduced populations because of the long length of the project and the results depend on the species, pollinators and habitat characteristics (Ramsay and Stewart 1998, Stewart et al. 2003, Ramsay and Dixon 2003). In consequence, data obtained after several years can not be conclusive for the establishment of reliable protocols to recover endangered populations. Schuiteman and Vogel (2003) enlist several aspects that must be considered when dealing real practical problems to conserve orchids. The selection of target species is one of these considerations and in situ as well as ex situ strategies could be made sometimes together (Brundrett et al. 2003). The selection of species for managed conservation processes can be mainly driven by two forces: the degree of endanger and the feasibility of propagation (Feuerherdt et al. 2005).

Because of working with endangered species in a particular habitat is not always possible, model species can also be selected such as those orchids that are well adapted to environmental changes and which seed bank is always easy to acquire. This can lead us to obtain useful information about efficiency of isolated fungus and also alternatives to manage attractive species that can be offered to botanical gardens. At the same time, this strategy can get the attention of amateurs and collectors without detrimental endan- gered populations and provide founds for financing long-term monitoring projects.

Since 2001, with the help of students, we started a project for symbiotic propagation of terrestrial orchids from southern Mexico City (see Rangel-Villafranco \& Ortega-Larrocea in the same volume). Two species of Mexico have been selected for starting monitoring reintroduction of populations. Seedlings were cultivated in vitro with mycorrhizal fungi and successfully reintroduced within a biological reserve located in Mexico City. Bletia urbana Dressler, is an endangered species with a infrequently seed production and very scarce seed bank collection and has been long-term documented (Ortega-Larrocea 2004). Despite the fact that natural populations are annually growing during the rainy season, after some years of monitoring we have realized that flowering is not produced each year and in consequence, seeds are not easy to get. Acquisition of capsules was done for the first time in 1984 (Martínez 1985, Rubluo et al. 1989) and for a second time in 2000. We have demonstrated that seeds of this species can be preserved without detrimental in their germination for more than 16 years only in a refrigerator (Ortega-Larrocea et al. 2000). Seedlings of B. urbana coming from both seed banks were introduced coinciding with the rainy season to promote survival (Castillo 2002). We have monitored growth for the past six years with a final survival of $c a .50 \%$. Means of plant sizes revealed that $B$. urbana requires several years to reach adulthood size. After five years, plants start to flower and seeds were subsequently collected to assess embryo viability (Fig.1A). More than $90 \%$ of seeds produced naturally by the reintroduced plant germinated in vitro (Fig. 2A). However, the continuity of this process has also been affected by natural conditions as high and prolonged precipitation, affect- 


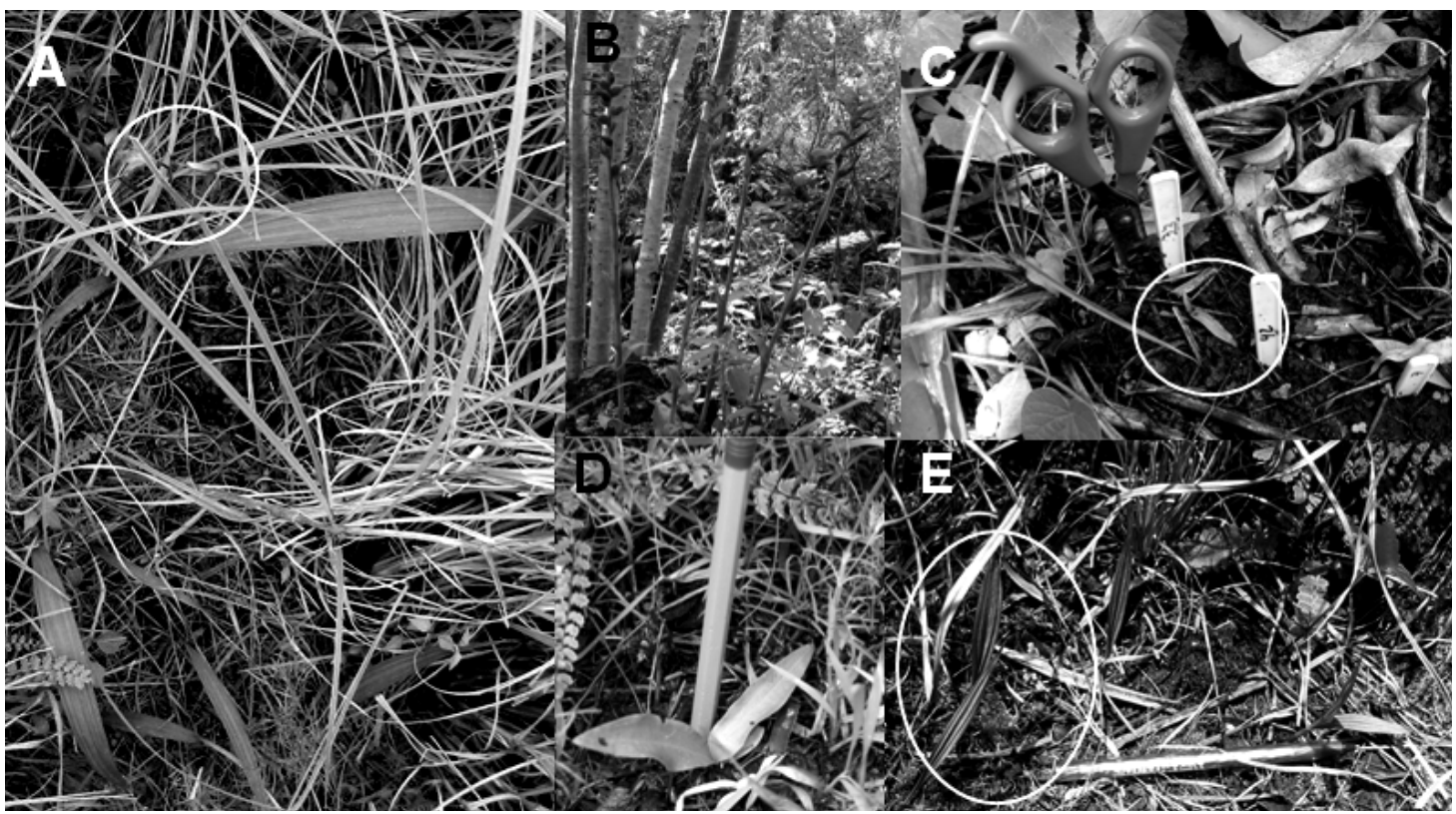

Figure 1. Bletia urbana. A. Flowering in natural conditions of symbiotic reintroduced seedlings. B. Native adult plant showing a lot of capsules. C. Dichromanthus aurantiacus plantlets emerging after two years of survival under natural conditions. D. Re-emerging plant after one year of reintroduction. E. Re-emerging plants after one year of survival into its habitat.

ing seed viability (Fig. 2B). Intact seeds that were not damaged while pathogen atack germinated as usual and we have demonstrated that self-propagation mechanism for this species has been reached naturally. The complete monitoring of this particular species will be published soon (Ortega-Larrocea et al., submitted).

We conducted further experiments to determine whether the seeds produced in 2005 could also germinate under natural conditions the following year (June 2006). Seeds baits were placed in situ in the vicinity of the adult plants and closely monitored. Preliminary results demonstrate that recovering protocorms in a short time is not feasible and most of the seeds that have been monitored remain with no germination after months (Fig. 2C).

The second species that we selected was a widespread and abundant terrestrial orchid Dichromanthus aurantiacus(La llave \& Lexarza) Salazar \& Soto Arenas. It seems that habitat perturbation favored the dispersion of this species and can currently be observed long distributed, in conserved habitat patches, as well as in road ways (Téllez 2002, Espejo et al. 2002, Hágsater et al. 2005). Contrary to B. urbana, D. aurantiacus flower each year and billions of seeds can be collected for many developed capsules (Fig. 1B). This plant, called cutsis, is very attractive to collectors and it is used for ornamentation (Hágstater et al. 2005). Symbiotic propagation has been done successfully by Rangel (2004) and recently reintroduction into their natural habitat in two successive years (2004 and 2005) (Rangel 2006). Reintroductions were performed into different microsites and have been monitored for the past two years. These orchids have been symbiotically propagated with fungi isolated from adult plants. During the first year (2005), $15 \%$ of survival was recorded for 91 reintroduced seedlings in five microsites. By the second year, less than $5 \%$ of this population re-emerged (Fig.1C). In 2005 , a second population of 131 seedlings was propagated with ten different isolates of fungi coming from adult plants as well as from protocorms obtained by seed baiting. Seedlings were reintroduced in 13 microsites within the same habitat and near a quarter of plants survive after a year. Survival and growth parameters indicate that there is not any short-term effect from the origin of the isolate (Rangel and Ortega-Larrocea in prep.). Microsite conditions as high organic matter and light seem to favor survival and play a fundamental role in plant development (1D). 


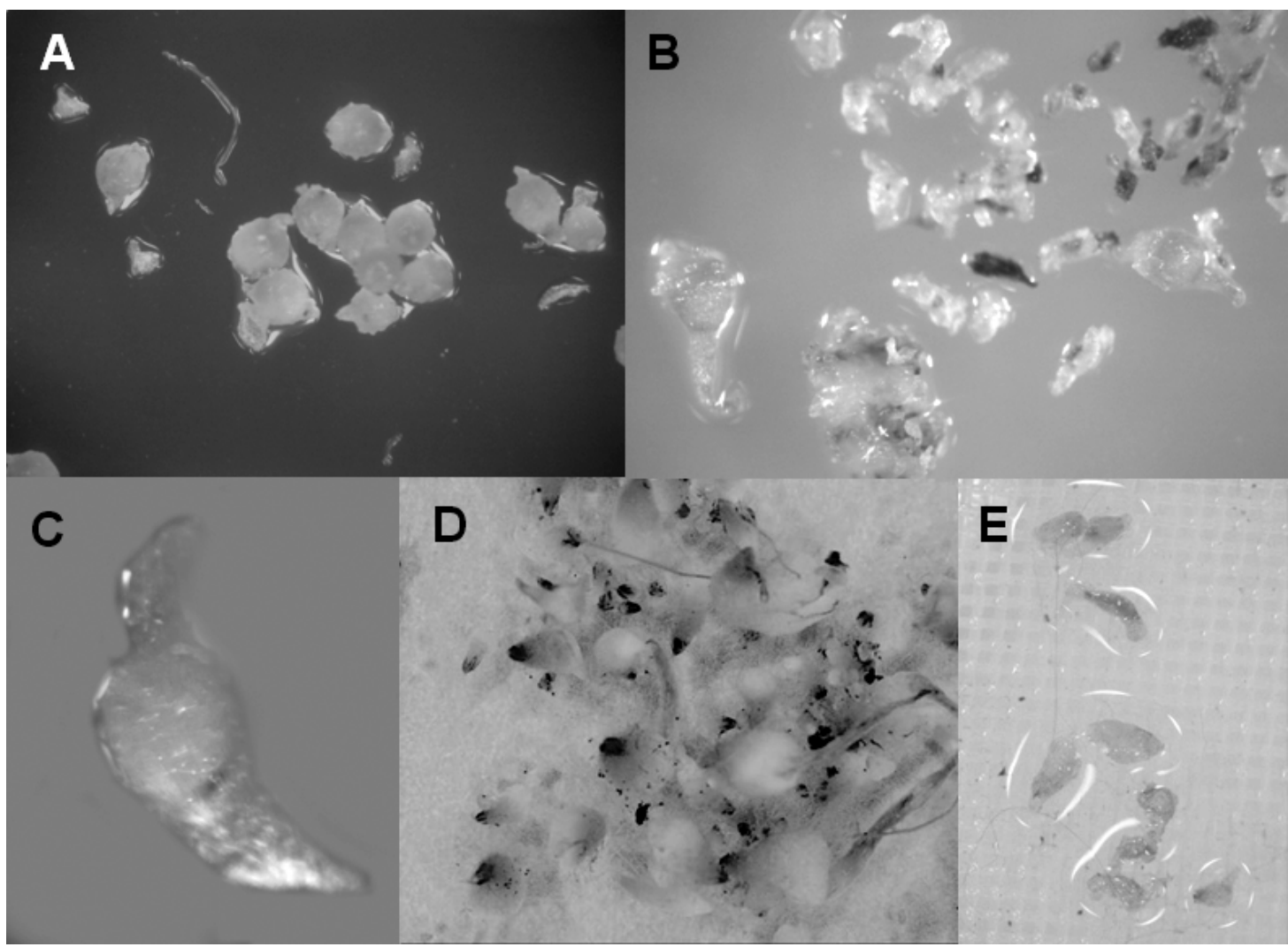

FiguRE 2. Bletia urbana A. Asymbiotic protocorms of B. urbana from a capsule of a reintroduced plant. B. Damaged seeds by natural conditions and some rescued in vitro protocorms from a reintroduced plant. C. embryo recovered in vitro after incubation in soil for months and produced by reintroduced plants in nature. Dichromanthus aurantiacus $\mathbf{D}$. seedlings obtained through baits. E. Imbibed seeds of Bletia campanulata after several months of incubation in soil.

The mycorrhizal fungi that made symbiotic associations with these two orchids belonged to two genus. Adult plants of $B$. urbana are associated naturally with Epulorhiza fungi and D. aurantiacus with Cerathorhiza. In vitro propagation has shown that $B$. urbana is easy to germinate even asymbiotically (Martínez 1991, Rubluo et al. 1993), it is less specific for isolates and can have association also with Ceratorhiza fungus (Rangel 2004). Dichromanthus auranticus can also be developed with some Epulorhiza isolates. However the low compatibility lead to obtain protocorms that do not overcome stage 3 and also asymbiotic germination is difficult to achieve (Rangel 2006). For both species, development of seedlings is faster and better when propagated with an isolate from the same adult species.

In situ germination showed that fungus specificity for D. aurantiacus with Cerathoriza is not random and iso- lates of this genus have been obtained when incubated in the rhizosphere of adult Bletia urbana. Baiting also reveals that this species can develop easily in few months during the rainy season (Fig. 2D) instead conditions for species of genus Bletia are not yet understood (Fig. 2C and E). We have hypothesized that light could be one of the factors that limits Bletia spp. germination but asymbiotic protocorms can be obtained in vitro when germinate in obscurity. This evidence could support the fact that in natural conditions, $D$. aurantiacus is more wide spread and seedlings can be found near adult populations also because seed production is regular in a lot of capsules. On the other hand, B. urbana seedlings have never been observed under natural conditions.

If analyzing the results of survival of reintroduced plants, recovery of $D$. aurntiacus could be less feasible that $B$. urbana because it is very poor and growth of reemerging plants is not increasing as a measure of adap- 
tation: see size of re-emerging B. urbana plants after a year compared with those of $D$. aurantiacus after two years (Fig.1C and E). Microsite conditions are influencing much more the survival of reintroduced plants of this wide spread species, contrary to what we can expect for. In contrast, management symbiotic propagation and reintroduction seems to favor the endangered B. urbana. This is because their high survival is less dependent on microsite conditions every year, and flowering and self pollination produce capsules with viable seeds. However, these results are preliminary examples of the successful reintroduction in pilot essays in natural conditions and are not conclusive. Further essays with symbiotic seedlings of the same species could not be repetitive, particularly in the case of $B$. urbana because we have not proved several isolates as we do for D. aurantiacus.

Meanwhile, we illustrate the fact that even when natural populations of some species are decreasing very fast, management can sometimes easily recover some species in a relatively short time. Also we open the question whether $D$. aurantiacus is so aggressive and widespread: it is because of a synergistic effect of reproduction and association with mycorrhizal partner that promote its survival in nature? Could it be the opposite for the endangered B. urbana and a poor seed bank possibly risked survival because fungus soil populations of Epulorhiza are less abundant or less infective? Further studies must be conducted in the short future to investigate whether other plant species of these two genus behave similarly. Working with these contrasting orchids in the same habitat lead us to learn important constraints about real management of species for restoration purposes and are quite interesting from the conservation point of view.

ACKNOWLEDGEMENTS. We are warmly acknowledged to Dr. Víctor Chávez to invite us to work in this field and Dr. L. Zettler for encouraging us appreciating our research work. Financial grants were obtained for Conacyt-Jóvenes a la Investigación Project No. 45243.

\section{LITERATURE CITED}

Batty, A.L., K.W. Dixon, M. Brundrett \& K. Sivasithamparam. 2001. Long-term storage of mycorrhizal fungi and seed as a tool for the conservation of endangered Western Australian terrestrial orchids. Aust. J. Bot. 49: 619-628.
Brundrett, M.C., A. Scade, A.L. Baty, K.W. Dixon \& K. Sivasithamparam. 2003. Development of in situ and ex situ seed baiting techniques to detect mycorrhizal fungi from terrestrial orchid habitats. Mycol. Res. 107: 12101220.

Castillo, M.M. 2002. Micorrización in vitro de Bletia urbana como una estrategia para su reintroducción. Tesis de licenciatura, Facultad de Ciencias, Universidad Nacional Autónoma de México. 52 p.

Espejo, S.A., C.J. García, F.A. López, M.R. Jiménez \& S.L. Sánchez. 2002. Orquídeas del Estado de Morelos. Orquídea (Méx.) 16: 332 p.

Feuerherdt, L., S. Petit \& M. Jusaitis. 2005. Distribution of mycorrhizal fungus associated whit the endangered pink-lipped spider orchid (Arachnorchis (syn. Caladenia) behrii) at Warren conservation park in south Australia. New Zeal. J. Bot. 43: 367-371.

Hágsater, E., M.A. Soto, G.A. Salazar, R. Jiménez, M.A. López \& R.L. Dressler. 2005. Las orquídeas de México. Instituto Chinoín, México, D. F. 302 p.

Martínez, P.A. 1985. Inducción in vitro de brotación múltiple en Bletia urbana Dressler (Orchidaceae) a partir de protocormos seccionados. Tesis Profesional. Facultad de Ciencias, UNAM. México. 66 p.

Martínez, P.A. 1991. Propagación masiva in vitro y recuperación de poblaciones de orquídeas en peligro de extinción. Tesis de Maestria. Facultad de Ciencias, UNAM. México. 107p.

Ortega-Larrocea, M.P., S.V.M. Luna-Rosales \& V.M. Chávez-Avila. 2000. Potencialidad de la micorrización masiva in vitro en la micropropagación de Bletia urbana (Orchidaceae). In: Resúmenes de la 1era. Reunión Iberoamericana y III Simposio Nacional sobre Micorriza, Guanajuato, México. Pp. 28.

Ortega-Larrocea M. P. 2004. Symbiotic reintroduction of terrestrial orchids in Mexico. II International Orchid Conservation Congress, Sarasota, Florida.

Ramsay, M.M. \& K.W. Dixon. 2003. Propagation science, recovery and translocation of terrestrial orchids. Pp. 259-286 in: K.W. Dixon, S.P. Kell, R.L. Barret \& P.J. Cribb. (eds.). Orchid conservation. Natural History Publications, (Borneo), Kota Kinabalu, Sabah.

Ramsay, M.M. \& J. Stewart. 1998. Re-establishment of the lady's slipper orchid (Cypripedium calceolus L.) in Britain. Bot. J. Linn. Soc. 126: 173-181.

Rangel, V.M. 2004. Aislamiento de hongos micorrízicos de orquídeas terrestres de la Reserva "El Pedregal" de San Angel, México. D. F. Tesis de Licenciatura, Facultad de Estudios Superiores, Iztacala, Universidad Nacional Autónoma de México. 113 p.

Rangel, V.M. 2006. Germinación simbiótica y reintroducción de orquídeas terrestres en la Reserva ecológica del Pedregal de San Angel, México, México D. F. Tesis de 
maestría, Posgrado en Ciencias Biológicas, Universidad Nacional Autónoma de México. 115 p.

Rubluo, A., V. Chávez \& A. Martínez. 1989. In vitro seed germination and re-introduction of Bletia urbana (Orchidaceae) in its natural habitat. Lindleyana 4: 68-73.

Rubluo, A., V. Chávez, A.P. Martínez \& O. MartínezVázquez. 1993. Strategies for the recovery of endangered orchids and cacti through in vitro culture. Biol. Conserv. 63: 163-169.

Schuiteman, A. \& E.Vogel. 2003. Pp. 55-68 in: K.W. Dixon, S.P. Kell, R.L. Barret \& P.J. Cribb. (eds.). Orchid conservation. Natural History Publications, (Borneo), Kota Kinabalu, Sabah.

Stewart, S.L., L.W. Zettler \& J. Minso. 2003. Symbiotic germination and reintroduction of Spiranthes brevilabris Lindley, an endangered orchid native to Florida. Selbyana 24: 64-70.

Téllez-Velasco, A. 2002. The Pedregal of San Angel and its orchids. Orch. Rev. 110: 25-9.

Whigham, D.F., J.P. O’Neill, H.N. Rasmussen, B.A. Caldwell \& M.K. McCormick. 2006. Seed longevity in terrestrial orchids - potential for persistent in situ seed banks. Biol. Conserv. 129: 24-30.

Zettler, L.W., J. Sharma, F.N. Rasmussen. 2003. Mycorrhizal diversity. Pp. 205-226 in: K.W. Dixon, S.P. Kell, R.L. Barret \& P.J. Cribb. (eds.). Orchid conservation. Natural History Publications, (Borneo), Kota Kinabalu, Sabah.

Pilar Ortega is Associated Professor at the Universidad National Autónoma de Mexico where she works as a researcher in the Instituto de Geología. She is interested in the association with mycorrhizal fungi in orchids and other plants, particularly arbuscular mycorrhizal fungi. She starts the direction of some students to develop a research project of orchid mycorrhizal fungi in Mexico and she is pioneer on this matter in this country.

Mónica Rangel, Master in Science graduated at the Universidad Nacional Autónoma de México in 2006. She is interested in the conservation of terrestrial orchids using symbiotic propagation and reintroduction into their natural habitat and the identification of mycorrhizal fungi. 